\title{
Disalignment of Political Parties in Indonesia : Study on the Declining Electability of Prosperous Justice Party (PKS) in General Election 2014
}

\author{
Suryani \\ Department of Political Science, Faculty of Social and Political Sciences UIN Jakarta, Indonesia \\ Doctoral Program Students of Political Sciences Department, FISIP UI, Indonesia \\ Suryani@uinjkt.ac.id
}

\begin{abstract}
Elections become the most important indicator of political party's electability. The earning votes in the general election becomes the measurement of success or failure of a political party for five years. The up and down experienced by political parties could not separated from how the political parties respond to any problems and political conflicts that occur at public. This led to the disalignment of political parties that give impact to the declining in the vote of political parties in the general election.
\end{abstract}

Disalignment is interpreted as the transfer of voters from one party to another party, due to several things, such as; the failure of party leadership, the occurrence of internal conflicts, the presence of other party alternatives, political party positioning issues related to the issue of national identity, and others.

One party that experienced disalignment was the Prosperous Justice Party (PKS). In the General Election 2009, PKS received $8,206,955(7.88 \%)$ votes with the seats of the House of Representatives 57 or $\mathbf{1 0 . 1 8 \%}$. While in the General Election 2014 there was a significant decrease of 8,480,104 (6.79\%) and 40 $(7.1 \%)$ of seats in the DPR. Some things are considered to be the cause of the declining numbers relating to issues of party leadership, internal conflicts, party positioning on government. The decline in PKS votes in the 2014 election was a response indicated by the constituency to what was happening in the organization itself.

Keyword: Disalignment, decline, electability, political party

\section{INTRODUCTION}

As the important institution in the democratic system, political parties must be able to maintain their existence either in the grass roots and their constituents or at the level of representative institutions which are the interpretation of the community for the fulfillment of their political rights as citizens.

The result of general election is an important indicator to measure the works of political party for five years in carrying out its function as a facilitator who's connecting the political public aspirations with the state policy. Nevertheless, the success of political parties in the election is not followed by the real work. Their work that should be effective and successful in the management of the state, in fact causing disappointment for constituents that can be seen in the declining votes acquisition in the next election.

The object of analysis is the Prosperous Justice Party (PKS), which since the beginning of the reformation era, has received serious attention from the public. In the 1999 General Election, the Party was named Justice Party (PK) and since the 2004 General Elections until now became the Prosperous Justice Party (PKS). As a new political party, and not a political party inherited from the New Order regime, with its constituents and solid members, PKS has always been in the top 5 winners of the general election. But, in the general election of 2014, this party experienced a substantial decline in votes from previous elections (2009). The vote decreased about $1.09 \%$ with the seats in the DPR down from 57 seats to 40 seats. This paper tries to analyze what factors cause the decline.

The phenomena of the declining votes of PKS in the general election of 2014 from 2009 election, can be analyzed by using the disalignment concept which is interpreted as the transfer of voters from one party to another due to several things, such as; the failure of party leadership, the occurrence of internal conflicts, the presence of the other alternative parties, political party positioning issues related to the issue of national identity, and others.

This issue is interesting to be examined deeply, as it sees the tendency of voters in Indonesia to be in the category of sociological and psychological voters where political choice is more motivated by matters relating to organizational, religious, social, and emotional attachment, and not the voter' rational that promotes the objective assessment of the community against the evaluation of the performance of the political parties it chooses.

\section{VOTERS AND DISALIGNMENT CONCEPT}

The concept of Disalignment matches with the realignment concept that can be used to analyze and evaluate the rise and fall of the result of the vote in a general election by comparing with the previous elections. This concept was used by Charles S. Mack in his book "When Political Parties Die: A Cross- 
National Analysis of Disalignment and Realignment". Mack defines disalignment as: "A severe loss of support for a major political party among its core base voters." And the realignment is defined as "A substantial, persistent, and pervasive transfer of support among medial voters from one major party to another."[2]

Disalignment becomes a logical consequence when a political party is considered failed to maintain the internal party management that directly relates to the mass of supporters of both members and sympathizers. Then the next is the abandonment of political parties by supporters which resulted in the decline of the vote in the general election. Mack divides the voters into 3 categories: Core Base Voter (CBV), Medial Voter (MV), and Peripheral Base Voter (PBV). The division of this category is similar to an analysis of voter behavior by the Sydney Verba that divides the voters into 3 characters: Psychological, Sociological and Rational Choice.

Core Base Voter (CBV) is interpreted as a party sympathizer in which voters are almost certain to vote for candidates from one particular party whoever the candidate offered by the party. [1] This category is similar to the sociological characteristics of voters in which the proximity of culture and proximity to the entered organization is the strong reason for choosing a particular party rather than on a particular individual who becomes a candidate [3]. Medial Voter (MV) is interpreted as a voter who is more focused on candidates to be elected and not to his political party [1], the characteristics of voters in MV are almost identical to the psychological category of voters who focus more on candidate orientation within political parties reinforced with full awareness about the importance of participating in politics and having a strong party identity [3]. Peripheral Base Voters (PBV) are voters who are almost identical to CBV but in this category they are more critical and easily divert their choice to other parties because they think that the previous election party is no longer considered appropriate to be a political aspiration [1] the characteristics of this PBV are the same as the category Rational Choice voters who prioritize critical calculations based on objective judgment, political cost and benefit considerations of one candidate or political party in the election [3].

One of political party that experience the decreasing votes is the Prosperous Justice Party (PKS). In the General Election of 2009 , PKS received votes about $8,206,955(7.88 \%)$ with the seats of the House of Representatives 57 or $10.18 \%$. While in the General Election 2014 there was a significant decrease of $8,480,104(6.79 \%)$ and $40(7.1 \%)$ of seats in the DPR. Some things are considered to be the cause of the decline in numbers relating to issues of party leadership, internal conflicts, party positioning on government. The decline in PKS votes in the 2014 election is a response indicated by the constituency to what is happening in the organization itself.
This article is written based on research that uses qualitative approach by using data collection methods through review and data analysis of several studies that have been done before.

\section{ABANDONMENT OF PKS BY CONSTITUENTS}

The political constellation in Indonesia does not guarantee the stability of the harmony relation between political parties and their constituents which can be expected to be a voting field in every General Election.

Some of the problems and political conflicts that occur both on a local and national scale can influence the tendency of the electorate in determining to whom and what party of political choices will be given. As it happened with PKS in the 2014 General Election, some of the problems that directly related to the party management changes and the issue of corruption involving the party elite, affected the acquisition of votes in the 2014 General Election. The $15 \%$ vote acquisition target, can only reach $6.79 \%$. PKS should conduct depth evaluation of why the numbers obtained differ significantly from those targeted, even down from the previous elections.

According to Mack, several reasons can be a factor causing disalignment of political parties, including: [1]

\section{Leadership failure}

2. Frequent division of issues and positioning related to national identity

3. Party alienation of CBV

4. The existence of alternative parties

5. Possibilities resulting from the application of the First Past the Post (FPP) election system [2]

In the case of PKS, the cause of the decline in vote acquisition in the 2014 election can be explained as follows:

\section{Leadership Failure}

The failure of leadership can be seen from the occurrence of a condition when one or some of party elites misjudged its position in confronting the constituents and the other party power configuration. [2] one of PKS's elite (former party president) Luthfi Hasan Ishaaq was sentenced to 16 years in prison. On December 9, 2013 by the Court of Justice of Jakarta Corruption Court, LHI was proved legally and convincingly committing corruption and money laundering (TPPU).

Cases affecting LHI provide a very significant effect for the decline in vote acquisition of PKS in the 2014 election. People directly can follow the chronology of cases conducted through the mass media. In addition, this case becomes a strategic material to be used by PKS political opponents either directly thrown in front of the public or through the framing media which is very influential for building public opinion especially 
ahead of the vote. According to Hidayat Nur Wahid as the chairman of DPP PKS in public policy dept, case of LHI has greatly affected the performance of PKS in elections 2014. It was shown inthe results of research conducted by Zaenal Arifin stating that the case of LHI greatly affected the PKS electability to decrease $1.09 \%$ elections in 2009 , whereas in 2014 the participation of the public was more prominent to reach $75 \%$ compared to the 2009 elections which only reached $70.1 \%$ of the total number of citizens who have the right to vote. [4]

2. Occurrence of issue and positioning divisions related to national identity

The placement of party positions strongly influences the $\mathrm{CBV}$ in determining its choice. From the beginning CBV has identified itself with the political party and believes that the selected party will not be out of its own identity. [2] But, at certain times the party can change its conservative identity and move into a new identity adjusting to the growing political dynamics. This raises the disappointment of CBV and into consideration whether the political choice will change or not.

The change of PKS image from a conservative party that carries the Islamic ideology to an open party, raises new issues that must be faced more seriously, at least two issues to be faced: first, convincing an orthodox traditional mass base that has been the main source of party votes. Second, convincing a new voter market that is still convinced by the new commitment built by the party. [5] The controversial policy raises internal conflict among party elites and splits it into two factions; a justice faction that represents party orthodoxy that is oriented towards ideological values and prosperous factions that support party policy with a pragmatic orientation.

Directly or not, the fundamental change of things that initially became the party's internal commitment has led to the disappointment of some constituents that adversely affect the image of political parties in elections.

\section{Party alienation of CBV}

The CBV alienation condition is a continuation of the party elite policy that does not consider CBV intentions as described in the second point. This raises the possibility that CBV will change into PBV while still waiting for the possibility that there will be another decision of the political party relating to the changed identity. This situation provides an opportunity for the competitor's party to offer itself as an alternative option despite the greater tendency in the case of the PKS that the CBV opt for abstentions in elections.

\section{The existence of an alternative party}

Alternative parties can be another consideration for $\mathrm{CBV}$ or PBV that is disappointed and transformed into an MV, because the issues raised are related to the performance of the party's elite, the shift of party identity and alienation caused by the ignorance of political parties against constituent aspirations.

Some other parties that have an ideological similarity with the PKS can be an alternative, though not close the possibility of voters will also glance at the party through the ideological line that had originally been a belief. [2]

Disalignment that occurs in the PKS in the 2014 general election was a serious matter of concern to party managers. This was in addition to the fact that it already has a potential $\mathrm{CBV}$, PKS has also experienced an increasing votes since the second election in 2004 especially when compared with when PKS was still a PK (Party of Justice) in the 1999 election. As a party that is considered to have uniqueness in the movement and policy breakthroughs to make it different from other political parties in the reform era, PKS has always been in the public spotlight of both its organization, party elite, and CBV to bring up many other sympathizers in the MV category who voted for the PKS and its candidate in the general election.

Many evaluations must be done by internal PKS if they want their constituents, $\mathrm{CBV}$, and MV commit them self to choose PKS in the 2019 election. Although there is one thing for sure in politics, that nothing is certain, everything depends on the performance and the hard working of the political party in attracting voters to support and win it in the election.

\section{References}

[1] Charles M. Mack, When Political Parties Die: Across-National Analysis of Disalignment and Realignment, Santa Barbara: Praeger, 2010

[2] Seta Basri, Partai Politik Pasca Reformasi antara Disalignment dan Realignment, http://setabasri01.blogspot.co.id

[3] Saiful Mujani, R. William Liddle, Kuskridho Ambardi, Kuasa Rakyat: Analisis tentang Perilaku Memilih dalam Pemilihan Legislatif dan Presiden Indonesia Pasca Orde Baru, Jakarta, Mizan, 2011

[4] Zaaenal Arifin, Sikap Politik Partai Keadilan Sejahtera Terhadap Kasus Lutfi Hasan Ishaaq Dalam Korupsi Impor Daging, UIN Sunan Kalijaga Yogyakarta, 2014

[5] Burhanuddin Muhtadi, Perang Bintang 2014: Konstalasi dan Prediksi Pemilu dan Pilpres, Jakarta: Naura Books, 2013 